\title{
Factors That Influence Technical Efficiency of Sorghum Production: A Case of Small Holder Sorghum Producers in Lower Eastern Kenya
}

\author{
Evaline Chepng'etich, ${ }^{1}$ Sospeter Onchoke Nyamwaro, ${ }^{2}$ \\ Eric Kiprotich Bett, ${ }^{1}$ and Kwena Kizito ${ }^{3}$ \\ ${ }^{1}$ Department of Agribusiness Management and Trade, Kenyatta University, P.O. Box 43844-00100, Nairobi, Kenya \\ ${ }^{2}$ International Center for Tropical Agriculture (CIAT), P.O. Box 6247, Kampala, Uganda \\ ${ }^{3}$ Kenya Agricultural Research Institute (KARI-Katumani), P.O. Box 340-90100, Machakos, Kenya
}

Correspondence should be addressed to Evaline Chepng’etich; chepngetichsang@yahoo.com

Received 30 April 2015; Accepted 25 June 2015

Academic Editor: Jixiang Wu

Copyright ( $(2015$ Evaline Chepngetich et al. This is an open access article distributed under the Creative Commons Attribution License, which permits unrestricted use, distribution, and reproduction in any medium, provided the original work is properly cited.

\begin{abstract}
Majority of the rural households in Kenya depend on agriculture as a source of food and livelihood. Agricultural productivity has been declining due to many factors resulting in increased food insecurity in the country. Consequently, there is a renewed interest in promoting drought-tolerant crops such as sorghum which thrives in the arid and semiarid lands of the developing world. However, performance of sorghum production among the smallholder farmers has still remained low. This study was thus carried out to identify factors that influence technical efficiency of sorghum production among smallholder farmers in Machakos and Makindu districts of the lower eastern Kenya. Collected data on farm and farmer characteristics were analysed by use of descriptive statistics and Tobit model. Result highlights show that technical efficiency was influenced positively by formal education level of the household, experience in sorghum farming, membership in farmers associations, use of hired labour, production advice, and use of manure. Surprisingly household size, meant to enhance labour, had a negative influence. To increase technical efficiency, efforts should focus on improving information flows on agronomic practices. Farmers should also be encouraged to form and actively participate in various farmers associations, which enhance learning and pooling of labour resources, hence improving technical efficiency.
\end{abstract}

\section{Introduction}

Grain sorghum, Sorghum bicolor (L.)Moench, is the fifth most important cereal crop grown in the world [1]. Probably because of its versatility and diversity [2], sorghum is mainly grown in the arid and semiarid lands (ASALs) of Africa and Asia for rural food security. The future of sorghum enterprise is linked to the contributions of sorghum to food security, income growth, and alleviation of poverty. This is more relevant in developing countries in the African continent than in other developed nations.

In Kenya sorghum is a traditional crop, which is grown in many parts of the country especially in the ASALs of the country. The crop lost favour with farmers when maize became the preferred crop and staple food after its introduction by the European settlers. However, due to the desire to stabilize food security in the country there is now renewed interest in promoting drought-tolerant crops such as sorghum, which are known to be well adapted to harsh environments [3].

A lot of research on sorghum breeding has been going on in Sub-Saharan Africa (SSA). Stable, high-yielding sorghum varieties (HYSVs) have recently been developed [4]. In Kenya, for example, the initiatives to promote sorghum production are mostly concentrated in the ASALs. Eastern Kenya is characterized by increasingly frequent drought occurrences, sometimes extending for two-to-three years in a stretch. Over the past two decades, there have been repeated 
maize crop failures in many parts of eastern Kenya especially because of droughts [5]. Sorghum promotion in this region is undertaken as a government strategy to enable the people to meet household food security needs and increase rural income $[3,6,7]$.

The area under sorghum production in Kenya has been increasing from 122,368 ha in 2005 to 173,172 ha in 2009, but the national average yield per hectare has been decreasing from 1.2 metric tons (MTs) per hectare to $0.5 \mathrm{MTs} /$ ha over the same period [8]. Several public efforts supplemented by those of nongovernmental organizations (NGOs) and other stakeholders like International Sorghum and Millet (INTSORMIL) program and International Crop Research Institute for the Semi-Arid Tropics (ICRISAT) have, for instance, provided interventions for harnessing opportunities for productivity enhancement (HOPE), targeted at improving productivity and marketing of sorghum. These interventions have included breeding, distribution of improved HYSVs that are pest and disease tolerant, and promotion of resource conserving management practices. In spite of all these efforts, there has been marked variability in production from the expected potential yields and the actual yields. The expected potential yield, for instance, for the Gadam sorghum variety is $2-2.5 \mathrm{MTs} / \mathrm{ha}^{-1}$ but farmers have only realized production of up to $1.2 \mathrm{MTs} / \mathrm{ha}^{-1}$ so far $[3,9]$. Variability in production is a function of differences in scales of operation, production technologies, operating environment, and operating efficiency [10]. Production increases depend mainly on the efficient use of available appropriate technologies but not necessarily on adoption rates of new technologies [11]. Chimai [12] noted that, for the small-holder farmers, variation in production due to differences in efficiency may be affected by various factors, which include regional and farm specific socioeconomic factors. For purposes of policy implications in efficiency analysis, it is very important to identify factors that influence efficiency. This study, therefore, aims at identifying the farm and farmer characteristics that influence levels of technical efficiency and estimating the marginal effects of these factors among the small holder sorghum producers in lower eastern Kenya.

Various studies have measured technical efficiency and its determinants among different types of farmers and countries, which provide useful information for this study. However, efficiency in these studies is relative and tends to be specific to farmers' groups and country under study. A number of empirical studies have attempted to investigate the relationship between technical efficiency and various socioeconomic variables and demographic factors such as levels of formal education, age, family size, access to credit, extension services, and experience [11-17]. However, technical inefficiency may arise primarily due to managerial incompetence and, therefore, efficiency differences could be explained in the context of the management characteristics such as training, experience, and motivation [16, 18, 19]. Other factors identified include membership in agricultural associations, land ownership, value of household assets, use of fertilizers, and tillage methods adopted [11, 17, 20, 21]. While some of the factors identified in studies can provide a general idea of what influences efficiency, generalization may not be possible because each country and agricultural product has unique characteristics.

There are many approaches used in the identification of these factors, which may vary to some extent with the methodology employed. The most commonly followed procedure in most of the approaches is what is usually referred to as the two-step procedure. In the first step, the efficiency or inefficiency score is estimated. Secondly, the estimated score is taken as a dependent variable and is then regressed against a number of other explanatory variables that are hypothesized to affect efficiency levels [22]. The various methods used in regression include ordinary least square (OLS) and Tobit regression models.

To achieve the objective of this study, the two-step procedure was employed where technical efficiency results from Chepng'etich's et al. [23] research were regressed against a number of explanatory variables hypothesized with the help of the Tobit regression model. Since technical efficiency scores lie between 0 and 1 , the dependent variable in the regression model did not have normal distribution. This suggests that the OLS regression was not appropriate and estimation with OLS would have led to biased parameters estimates. The technical efficiency scores were continuous; hence, Probit and Logit models could not be used either because they are only used when the dependent variable takes two values [24]. The Tobit regression model appeared to offer the most preferred option. In addition, most Data Envelopment Analysis (DEA) based studies present the second stage regression as Tobit model as the efficiency scores fall in the range of 0 to $1[16,25-27]$. This study therefore used Tobit model in identifying various farm and farmer characteristics that influence efficiency as described by Chepngetich et al. [23].

\section{Materials and Methods}

2.1. Study Area and Population. This study was conducted in Makindu and Machakos districts of Makueni and Machakos counties, respectively. They are situated in semiarid parts of Eastern Kenya. Their soils are lixisols and they both experience bimodal rainfall distribution pattern with two main distinct cropping seasons. Normally, the long rains of these districts fall from March to May, while the short rains fall from October to December. Machakos district lies at $1^{\circ} 35^{1} \mathrm{~S}$ and $37^{\circ} 10^{1} \mathrm{E}$ and has a mean annual rainfall of $690 \mathrm{~mm}$, with average annual temperatures ranging from a minimum of $11.0^{\circ} \mathrm{C}$ to a maximum of $27.6^{\circ} \mathrm{C}$. Makindu district lies at $2^{\circ} 0^{1} \mathrm{~S}$ and $37^{\circ} 40^{1} \mathrm{E}$ with a mean annual rainfall of $580 \mathrm{~mm}$ and average annual minimum and maximum temperatures of $14.5^{\circ} \mathrm{C}$ and $31.5^{\circ} \mathrm{C}$, respectively [23].

The population of interest for this research comprised sorghum growing households (HHs) in selected districts in the lower eastern Kenya, at least the HHs that grew sorghum in the 2010-2011 cropping season. A sample size of 143 farm households, 71 and $72 \mathrm{HHs}$ in Makindu and Machakos districts, respectively, was determined proportionately using the total population of the districts. A multistage sampling procedure was employed. First sorghum farmers 
were selected using purposive sampling method with the help of extension officers in the two districts and then the selected farm households were subjected to systematic simple random sampling where every 9th sorghum farmer was selected to achieve the required sample size.

Data was collected from sorghum farmers between June and August 2012 by use of pretested semistructured questionnaires administered by trained enumerators. Information on demographic, institutional, physical, and socioeconomic factors, yields, and inputs used to grow sorghum by each $\mathrm{HH}$ in 2010-2011 cropping season was collected.

2.2. The Tobit Model. An econometric analysis (censored regression model) based on the two-limit Tobit model was used to identify farm and farmers characteristics affecting smallholder efficiency in sorghum production. This was undertaken with the help of STATA software program. The technical efficiency scores generated from DEA model as described by Chepngetich et al. [23] were then regressed on the selected farm and farmer characteristics variables in order to identify their influence on technical efficiency. Technical efficiency scores range between 0 and 1 ; hence the two-limit Tobit regression model [22] was used as shown below:

$$
\begin{gathered}
U_{i}^{*}=\beta_{0}+\sum_{j=1}^{k} \beta_{j} Z_{i j}+\mu_{i}, \\
U_{i}= \begin{cases}1 & \text { if } U_{i}^{*} \geq 1 \\
U^{*} & \text { if } 0 \prec U_{i}^{*} \prec 1 \\
0 & \text { if } U_{i}{ }^{*} \leq 0,\end{cases}
\end{gathered}
$$

where $i$ refers to the $i$ th decision making unit (DMU); $U_{i}$ is the efficiency scores of the $i$ th DMU; $U_{i}{ }^{*}$ is the latent efficiency; $\beta_{j}$ are parameters to be estimated; $\mu_{i}$ is an error term that is independently and normally distributed with mean zero and common variance of $\delta^{2}\left(\mu_{i}\right.$ NI $\left.0 ; \delta^{2}\right)$; and $Z_{i j}$ are host of farm and farmers characteristics variables. Thus, the Tobit model used in this study is specified as follows:

$$
\begin{aligned}
\text { Eff score }= & \beta_{0}+\beta_{1} \text { Malehd }+\beta_{2} \mathrm{H} / \text { age }+\beta_{3} \mathrm{H} / \text { edu } \\
& +\beta_{4} \text { Prodadvice }+\beta_{5} \text { Adptill } \\
& +\beta_{6} \text { Hlabortill }+\beta_{7} \text { Offincm }+\beta_{8} \text { Asset } \\
& +\beta_{9} \text { Agrcredit }+\beta_{10} \text { Othrincm } \\
& +\beta_{11} \text { Srgmfarmsize }+\beta_{12} \text { Ndependents } \\
& +\beta_{13} \text { Srgmseed }+\beta_{14} \text { Manure } \\
& +\beta_{15} \text { Improvseed }+\beta_{16} \text { Clubmbr } \\
& +\beta_{17} \text { Expr }+\mu_{i},
\end{aligned}
$$

where Eff score is efficiency score, Malehd is male-headed household, H/age is age of household head, H/edu is formal education of household head; Prodadvice is production advice, Adptill is land preparation method, Hlabortill is hired labour, Offincm is off-farm income, Asset is assets, Agrcredit is agricultural credit, Othrincm is other income, Srgmfarmsize is sorghum farm size, Ndependents is number of dependents, Srgmseed is sorghum seed rate used, Manure is manure use, Improvseed is improved seed, Clubmbr is club member, and Expr is experience in sorghum farming.

\section{Results and Discussion}

\subsection{Descriptive Analysis}

3.1.1. Farmer Socioeconomic Characteristics/Profiles. Majority of the households surveyed in the region were male-headed with less than a quarter of the total sampled population being female-headed. Specifically, about $72 \%$ of the households in Machakos and $80.3 \%$ in Makindu were male-headed. Most of the sampled household heads had low levels of formal education. Almost half (46\%) of all the farmers captured in the survey terminated their formal education at primary level, $14 \%$ of the $\mathrm{HH}$ heads ( $\mathrm{HHHs}$ ) having not attended any formal school at all. It is noted that up to about $63 \%$ of the sampled HHs had less than 5 years of sorghum farming experience, while $37 \%$ had more than 5 years of the same farming experience. The number of years of sorghum farming experience differs across the region. For instance, a high number of the sampled farmers $(86.1 \%)$ had less than 5 years of the farming experience in Machakos district, while less than $14 \%$ had more than five-year experience in the same district. In Makindu, $61 \%$ of the sample had more than five years of the sorghum farming experience.

In terms of age, most of the sampled $\mathrm{HHH}$ s were relatively old as indicated by the mean age in each category. The youngest sampled HHHs were 28 and 32 years old, while the oldest $\mathrm{HHH}$ was 100 and 94 years old in Machakos and Makindu districts, respectively, with an average age of 55 years in both districts as shown in Table 1. Among all the surveyed $\mathrm{HHHs}$, the young $\mathrm{HHH}$ in the 18-35 years age bracket were only $5 \%$ and middle-aged HHHs between 36 and 50 years old constituted $36 \%$, while the majority of the sampled HHHs (51\%) were in the age bracket of 51-70 years. Only $8 \%$ of the HHHs were above 70 years old.

The HHs with smallest household sizes had two persons, while those with largest $\mathrm{HH}$ sizes had 17 persons, with an average of six members per household as summarized in Table 1 . About $96 \%$ of the total sampled HHs had at most 10 persons, while approximately $25 \%$ of the household surveyed had six persons per household in the region. Household assets ranged from KES 104,000 to KES 2.1 million with a mean of about KES 650,000. Eighty percent of the households had assets value falling below KES 1 million.

3.1.2. Farm Characteristics. Most of the land parcels used for sorghum production were individually owned. Only $6 \%$ of the sampled households owned land communally, while $1 \%$ owned land through leaseholds. The smallest size of land used for sorghum production was $0.025 \mathrm{ha}$, while the largest was 4.04 ha, with an average land size of 0.35 ha dedicated for sorghum production (Table 2). Ninety-seven 
TABLE 1: Summary of descriptive statistics of selected farmer and farm characteristics in the lower eastern Kenya.

\begin{tabular}{|c|c|c|c|c|c|c|c|}
\hline Dist. & Variables & Unit of measurement & $N$ & Mean & Std. dev. & Min & Max \\
\hline \multirow{9}{*}{ Machakos } & Age of HH head & Years & 72 & 55.28 & 12.693 & 28 & 100 \\
\hline & Household size & Number of people & 72 & 5.57 & 2.028 & 2 & 10 \\
\hline & HH dependants & Number of people & 72 & 3.75 & 2.199 & 0 & 9 \\
\hline & HH wealth & Kenya shillings & 72 & $601,455.60$ & $472,714.930$ & 104,000 & $2,147,000$ \\
\hline & Land sizes for sorghum production & Hectares & 72 & 0.17 & 0.167 & 0.025 & 0.81 \\
\hline & $\mathrm{HH}$ off-farm income & Kenya shillings & 72 & $26,683.61$ & $34,107.0017$ & 0.00 & 134,000 \\
\hline & Sorghum labour use & Person days ${ }^{\mathrm{a}}$ & 72 & 21.55 & 17.6042 & 2 & 79 \\
\hline & Sorghum output & Kilograms & 72 & 117.32 & 170.53 & 4 & 720 \\
\hline & Seed rate & $\mathrm{Kg} / \mathrm{ha}$ & 72 & 12.58 & 7.59 & 0.08 & 39.60 \\
\hline \multirow{9}{*}{ Makindu } & Age of HH head & Years & 71 & 54.61 & 12.777 & 32 & 94 \\
\hline & Household size & Number of persons & 71 & 6.66 & 2.651 & 2 & 17 \\
\hline & HH dependants & Number of persons & 71 & 5.38 & 2.925 & 0 & 16 \\
\hline & HH wealth & Kenya shillings & 71 & 704349.3 & 437032.428 & 125000 & 1725000 \\
\hline & Land sizes for sorghum production & Hectares & 71 & 0.53 & 0.167 & 0.101010 & 4.04 \\
\hline & $\mathrm{HH}$ off-farm income & Kenya shillings & 71 & 26693.52 & 29707.375 & 0.00 & 110,000 \\
\hline & Sorghum labour use & Person days $^{\mathrm{a}}$ & 71 & 37.74 & 31.473 & 4 & 180 \\
\hline & Sorghum output & Kilograms & 71 & 322.30 & 302.354 & 18 & 1350 \\
\hline & Seed rate & $\mathrm{Kg} / \mathrm{ha}$ & 71 & 7.95 & 4.63 & 1.24 & 20 \\
\hline \multirow{9}{*}{ Overall } & Age of $\mathrm{HH}$ head & Years & 143 & 54.94 & 12.693 & 28 & 100 \\
\hline & Household size & Number of persons & 143 & 6.11 & 2.028 & 2 & 17 \\
\hline & HH dependants & Number of persons & 143 & 4.56 & 2.199 & 0 & 16 \\
\hline & HH wealth & Kenya shillings & 143 & 652542.7 & $456,671.229$ & 104,000 & $2,147,000$ \\
\hline & Land sizes for sorghum production & Hectares & 143 & 0.35 & 0.443 & 0.025 & 4.04 \\
\hline & HH off-farm income & Kenya shillings & 143 & $26,688.53$ & $34,885.622$ & 0.00 & 134,000 \\
\hline & Sorghum labour use & Person days ${ }^{\mathrm{a}}$ & 143 & 29.59 & 26.632 & 2 & 180 \\
\hline & Sorghum output & kilograms & 143 & 219.09 & 264.92 & 4 & 1350 \\
\hline & Seed rate & $\mathrm{Kg} / \mathrm{ha}$ & 143 & 10.28 & 6.69 & 0.08 & 39.60 \\
\hline
\end{tabular}

Notes: ${ }^{\mathrm{a}} 1$ person day $=8 \mathrm{hrs}$ work per day for an adult person; HH: household and Dist.: district.

TABLE 2: Summary of descriptive statistics of selected farm characteristics in the lower eastern Kenya.

\begin{tabular}{|c|c|c|c|c|c|c|c|}
\hline Dist. & Variables & Unit of measurement & $N$ & Mean & Std. dev. & Min & Max \\
\hline \multirow{5}{*}{ Machakos } & Land sizes for Sorghum production & Hectares & 72 & 0.17 & 0.167 & 0.025 & 0.81 \\
\hline & $\mathrm{HH}$ off-farm income & Kenya shillings & 72 & $26,683.61$ & $34,107.0017$ & 0.00 & 134,000 \\
\hline & Sorghum labour use & Person days ${ }^{\mathrm{a}}$ & 72 & 21.55 & 17.6042 & 2 & 79 \\
\hline & Sorghum output & Kilograms & 72 & 117.32 & 170.53 & 4 & 720 \\
\hline & Seed rate & $\mathrm{Kg} / \mathrm{ha}$ & 72 & 12.58 & 7.59 & 0.08 & 39.60 \\
\hline \multirow{5}{*}{ Makindu } & Land sizes for sorghum production & Hectares & 71 & 0.53 & 0.167 & 0.101010 & 4.04 \\
\hline & $\mathrm{HH}$ off-farm income & Kenya shillings & 71 & 26693.52 & 29707.375 & 0.00 & 110,000 \\
\hline & Sorghum labour use & Person days ${ }^{a}$ & 71 & 37.74 & 31.473 & 4 & 180 \\
\hline & Sorghum output & Kilograms & 71 & 322.30 & 302.354 & 18 & 1350 \\
\hline & Seed rate & $\mathrm{Kg} / \mathrm{ha}$ & 71 & 7.95 & 4.63 & 1.24 & 20 \\
\hline \multirow{5}{*}{ Overall } & Land sizes for sorghum production & Hectares & 143 & 0.35 & 0.443 & 0.025 & 4.04 \\
\hline & $\mathrm{HH}$ off-farm income & Kenya shillings & 143 & $26,688.53$ & $34,885.622$ & 0.00 & 134,000 \\
\hline & Sorghum labour use & Person days ${ }^{\mathrm{a}}$ & 143 & 29.59 & 26.632 & 2 & 180 \\
\hline & Sorghum output & kilograms & 143 & 219.09 & 264.92 & 4 & 1350 \\
\hline & Seed rate & $\mathrm{Kg} / \mathrm{ha}$ & 143 & 10.28 & 6.69 & 0.08 & 39.60 \\
\hline
\end{tabular}

Notes: ${ }^{\mathrm{a}} 1$ person day $=8 \mathrm{hrs}$ work per day for an adult person; HH: household and Dist.: district. 
percent of the sampled HHs used less than 1 ha of land to grow sorghum out of which majority of them (about $30 \%$ ) used 0.1 ha to grow sorghum. Land sizes planted with sorghum were conspicuously different among households in the two districts. As observed in Table 2, the average land sizes planted with sorghum were $0.17 \mathrm{ha}$ and $0.52 \mathrm{ha}$ in Machakos and Makindu districts, respectively. Majority of the households in Makindu planted sorghum on 0.40 ha land sizes, as opposed to majority of households in Machakos who planted sorghum on 0.1 ha land sizes.

It is observed that most of the households used improved varieties of sorghum seeds like the Gadam, Seredo, and Serens varieties. The farmers used seed rates ranging from $0.08 \mathrm{~kg} / \mathrm{ha}$ to $79 \mathrm{~kg} / \mathrm{ha}$ with a mean seed rate of $10.7 \mathrm{~kg} / \mathrm{ha}$ as summarized in Table 2. Twenty-six percent of the farmers used the recommended seed rate of $10 \mathrm{~kg} / \mathrm{h}$. Twenty-five percent used seed rate of $5 \mathrm{~kg} / \mathrm{ha}$ which is half the recommended seed rate, while $18 \%$ used double the recommended rate of $20 \mathrm{~kg} / \mathrm{ha}$.

Methods of land preparation varied among the surveyed HHs, but the most common method practised was use of ox-plough which up to $60 \%$ of the respondents used. Thirty percent of the surveyed households did not prepare their land before planting, whereas not more than $10 \%$ of the HHs used hand digging as a land preparation method before planting. In more specific terms, majority of the households in Makindu district never prepared their land before planting as was observed that $62 \%$ of all the sampled HHs in Makindu district did not actually plough their farms before planting. However, about $38 \%$ of the Makindu sampled HHs who ploughed their farms before planting did so using the ox-ploughing method. Although none of the sampled $\mathrm{HHs}$ in Makindu used hand digging as a land preparation method, approximately $20 \%$ of the sampled HHs prepared their sorghum planting land using hand digging in Machakos district.

Most often some farmers spread manure in their farms before planting. Half of the sampled households used manure, while the remaining half did not. The labour used in the sorghum production was mainly provided by family members. Only $36 \%$ of the sample used hired labour in one or more of the activities undertaken during the sorghum production processes. Hired labour was engaged mainly during land preparation, especially by those households who used ox-ploughing method. More labour was used in sorghum farms, especially during bird scaring where up to 10 hours per day could be spent in the farm during that period in which the whole bird scaring operation lasted for about three-to-four weeks.

3.1.3. Economic Activities. Households in lower eastern region of Kenya engaged in various economic activities as sources of earning incomes. These activities ranged from crop farming, livestock keeping, charcoal burning, small businesses, and formal employment to casual labour employment. Most of the households depended on farming as their only source of income. Fifty-four percent depended on farming as a sole income earner to meet the household daily requirements, while the rest of the sampled population

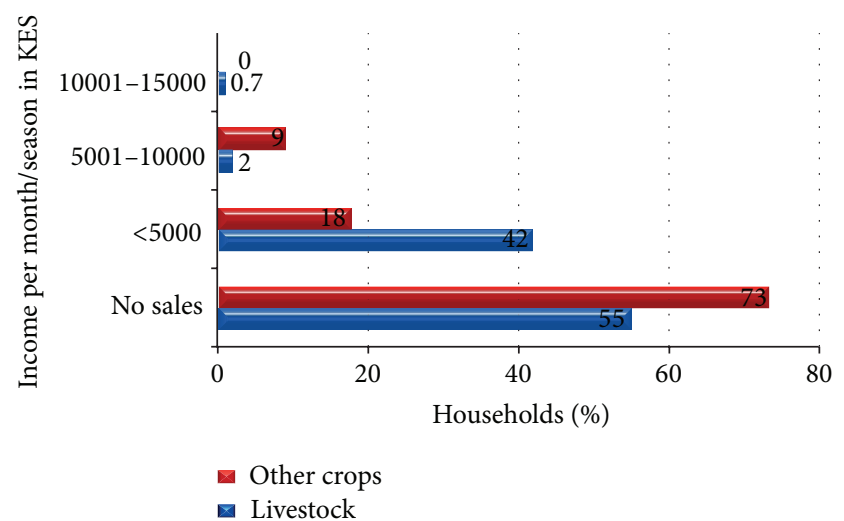

FIGURE 1: Source of income from livestock and other crops in the lower eastern Kenya. Source: survey results [23].

were either employed, having small businesses, or involved in casual labour employment in addition to farming.

Most of households (78\%) earned less than KES 3,000 per month as off-farm income. Thirty percent of them did not access any off-farm income. Most of crops grown in the region were maize, green grams, pigeon peas, beans, sorghum, sweet potatoes, and vegetables such as kales, spinach, and tomatoes. Livestock kept by the farmers were mainly goats, chicken, and bees with a few farmers having cattle especially oxen to provide animal power for ploughing and pulling ox-cart for carrying water and other farm produce. More than half of the households surveyed did not get any income from their crops and livestock because they produced mainly for subsistence and only sold the surplus, which was hardly there. Only a few earned more than KES 5,000 per month from livestock or per season in case of crops (Figure 1).

3.1.4. Transport and Communication. The market proximity from the farms was on average $20 \mathrm{~km}$ away where the sampled farmers spent an average of KES 150 in one return journey. The return distances travelled by the sampled $\mathrm{HHs}$ to markets ranged from half a kilometer to about $40 \mathrm{~km}$. The most commonly used available means of transport was motorcycles. However, a motor vehicle was available once or twice a week only during the open market days for those HHs living in the most interior regions.

3.1.5. Access to Agricultural Credits and Extension Services. While it is known that access to credits for sorghum production and marketing is important, it was observed that only a few sampled $\mathrm{HHs}(7 \%)$ accessed necessary agricultural credits. A majority of the sampled HHs (93\%) did not access any credits for sorghum production and marketing.

It was also observed that a reasonable proportion of sampled households $(50 \%)$ received production advice from extension services. The most common advice given was on agronomic practices and the best varieties to grow in the ASALs environment. These pieces of advice were received by a majority of the sampled respondents $(80 \%)$. Only $28 \%$ 
of the respondents were given information on availability of good markets. In addition, households belonging to farmers clubs or association were $57 \%$.

\subsection{Factors Influencing Technical Efficiency. Many variables} were found to influence technical efficiency of sorghum production in the lower eastern Kenya. Out of the 18 variables analysed, seven were found to influence technical efficiency positively and were found to be statistically significant at 5\% level as shown in Table 3. These variables include education levels of household heads in terms of years spent in formal schooling, number of years of experience in sorghum farming, $\mathrm{HH}$ membership in farmer clubs or associations, size of land planted with sorghum, hired labour, use of manure, and production advice on sorghum production. This implies that increasing use of these factors in the sorghum production processes would improve technical efficiency of sorghum production. Only one variable, the size of $\mathrm{HHs}$, was found to influence technical efficiency negatively and was found to be statistically significant at 5\% level.

Experience in sorghum farming was found to be positive and significant at 5\% level. This implies that as years pass with continuous sorghum farming, farmers tend to increase their capacity to do better in sorghum farming; hence, they become more technically efficient. Over time, the farmers are better placed to acquire more knowledge and skills necessary for choosing appropriate new farm technologies. These findings are in line with those of Gul et al. [28] and Padilla-Fernandez and Nuthall [27] but are contrary to those of Ajewole and Folayan [29].

Household heads with more years of formal schooling were found to be more efficient than their counterparts with less years of formal schooling. These results are in agreement with the findings of Amaza et al. [30], Nyagaka et al. [17], Chirwa [21], Shehu et al. [31], Ajewole and Folayan [29], Elibariki and Shuji [32], Mussa et al. [25], Idiong [33], and Njeru [34]. All these studies have argued that producers with high formal education levels ( $\geq 12$ years) are able to detect and reduce inefficiency in production. Formally educated farmers are generally better placed to receive, interpret, and respond to new information. Education increases chances to adopt and respond rapidly to the use of improved appropriate technologies such as water harvesting and soil conservation technologies and the agronomic practices. Less educated farmers are less receptive to improved farming techniques and provide poor supervision on their farms [34, 35].

Membership in farmer clubs or associations influenced positively technical efficiency. This suggests that households that belonged to farmer associations or clubs or related organizations were more likely to benefit from better access to inputs such as improved sorghum varieties and information on improved farming practices. Similar results were also realised by Kariuki et al. [20], Nchare [36], Wakili [35], Idiong [33], Shehu et al. [31], Chiona [11], Nyagaka et al. [17], and Chirwa [21]. Being a member of an organisation provides an avenue for information and technology transfer by extension agents and often leads to sharing of information even among members themselves. This enables the household heads to make appropriate decisions, which in the long run enhance productivity and efficiency. Moreover, in some farmer associations, certain farming practices and new technologies are undertaken together as a group. These practices enhance learning and pooling of labour resources.

The area planted with sorghum had a significant direct relationship on technical efficiency only in Makindu district. This indicates that efficiency of sorghum production increases with size of land under sorghum, but this relationship was not significant in Machakos district. Notably, most of the households in Makindu planted sorghum on larger farms as compared with those in Machakos hence engaging hired labour in the production of sorghum. Hired labour is highly associated with efficiency because of its high productivity per unit labour. Similar positive results of farm size and technical efficiency have been observed by Chiona [11], Chirwa [21], Elibariki and Shuji [32], and Gul et al. [28], but on the contrary Chimai [12] and Javed et al. [26] found that size of land planted with sorghum had a negative influence on technical efficiency.

Hired labour had a positive and statistically significant relationship with technical efficiency at 5\% level. Use of hired labour proved more efficient than family labour in the production of sorghum. The productivity per unit of hired labour was high. This could be attributed to the fact that hired labour acts as an incentive for the households to be more efficient in supervisory role because of the cost incurred. Comparable results were reported by Elibariki and Shuji [32] and Chimai [12].

Production advice given to the sorghum producing households had a direct and significant relationship with technical efficiency. Production advice increased technical efficiency. This corroborates with the work of Chiona [11], Nchare [36], Amaza et al. [30], Ajewole and Folayan [29], Javed et al. [26], and Wakili [35]. Through such production advice, farmers were able to get first-hand information on new agricultural innovations and techniques that would ensure increased sorghum production in the study area.

Interestingly, the size of the household was negative and significant at 5\% level in explaining the technical efficiency, implying that, as the household size expanded, the technical efficiency of sorghum production decreased. Similar results were obtained by Chimai [12], Nchare [36], Yusuf and Malomo [13], and Mussa et al. [25] who all found out that $\mathrm{HH}$ size had a negative influence on technical efficiency. On the contrary, Ajewole and Folayan [29], Shehu et al. [31], and Wakili [35] found that household size was positive and significant in explaining technical efficiency. The researchers argued that household size increased the labour available, hence increase in the technical efficiency. But, according to Nchare [36], it is observed that although household size increases the labour available for production, it is usually associated with production inefficiency hence technical inefficiency. This can be explained by the abundance of that available labour at farm level, which will lower the productivity per unit labour.

Other variables such as male-headed households, number of dependants, household assets, use of improved seed varieties, seed rate, household off-farm incomes, income 


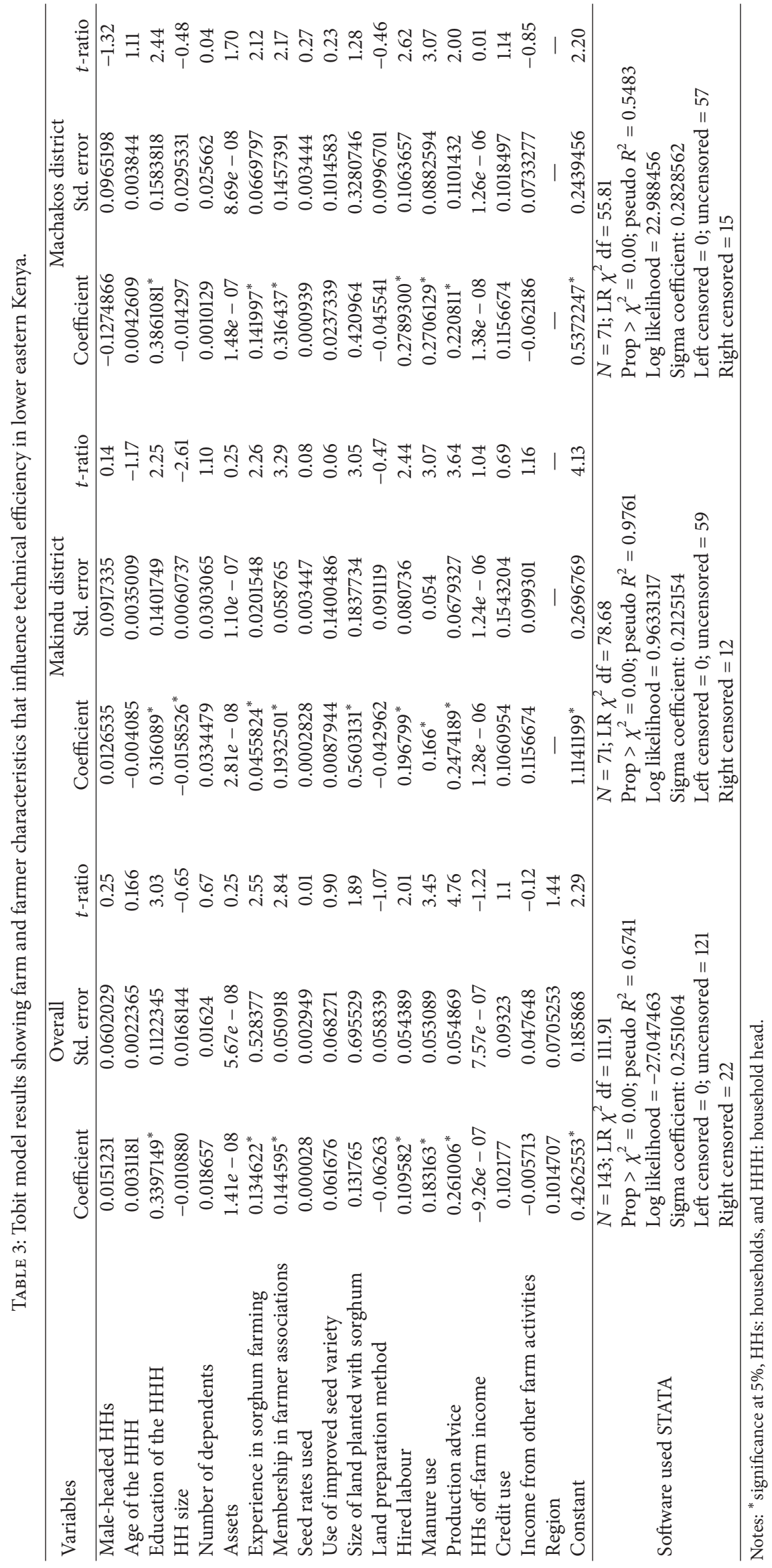


from other farm activities, and use of credits were positive for technical efficiency but not necessarily significant at 5\% level. Variables such as age of the household head and land preparation methods were actually negative for technical efficiency and were not significant at 5\% level.

Despite being expected to influence technical efficiency negatively, age of the $\mathrm{HHH}$ was found to vary between the districts. In Makindu, age of the $\mathrm{HHH}$ had the expected positive sign although it was not significant. Amaza et al. [30] argued that older farmers were likely to be less efficient than younger ones. This is because younger farmers were likely to be more progressive and more willing to adopt new agronomical practices hence higher efficiency in production. On the other hand, Elibariki and Shuji [32] found age of the household head to have a positive influence on technical efficiency. This argument was based on the assertion that as farmers grow old they gain more experience in the production of various agricultural practices; hence they become more efficient.

Assets possessed by the household had the expected positive sign though not significant. According to Chimai [12] assets are taken to indicate the household wealth status. In regard to smallholder farmers, assets are expected to influence technical efficiency positively. This is because assets act as shock absorbers, especially when sold off in times of need. The income from the assets could be used to purchase inputs and to hire various production practices.

Credit use was found to have the expected positive sign though not significant at 5\% level. As argued by Nchare [36] and Amaza et al. [30] credit was expected to reduce the financial difficulties the farmers usually face especially at the beginning of the production process. The credit could enable the farmers to have the capital to purchase inputs and to have resources to prepare their land on time before planting. Padilla-Fernandez and Nuthall [27] argued that credit to the farmers may act as an instrumental motivation to produce more efficiently apart from being able to purchase the required inputs for production.

Seed rate was expected to influence technical efficiency negatively but on the contrary it had a positive sign though not significant at $5 \%$ level. This could be attributed to most of the households found using low seed rate compared with the recommended rates. Overall, household sites were tested and those households residing in Makindu were positive but not significant. This means that belonging to Makindu was not enough to significantly influence a farmer to attain higher levels of efficiency.

In Machakos district, education of the household head, experience in sorghum farming, membership in farmers associations, manure use, and farmers receiving production advice were all positive and displayed 5\% significant levels. Other variables such as age of the household head, number of dependants, assets possessed by the households, seed rate of sorghum used, use of improved seed varieties, size of land planted, use of credits, and amount of household off-farm income were all positive for technical efficiency although they did not display significant differences at 5\% level. Variables such as male-headed households, household size, land preparation method, and income from other farm activities were negative for technical efficiency and were not significant at $5 \%$ level.

The differences in the two districts occurred in variables such as size of land planted with sorghum, which was positive for technical efficiency in Machakos district, while negative in Makindu district though not significant at 5\% level in both districts. Household size was negative for technical efficiency and significant at 5\% level in Makindu, while in Machakos though negative for technical efficiency it was not significant at $5 \%$ level. Other variables that displayed differences were male-headed households and income from other farm activities, which were both positive for technical efficiency in Makindu district but negative for technical efficiency in Machakos, though they were all not significant at $5 \%$ level in both districts.

3.3. Marginal Effect Analysis. The results from the Tobit model were also subjected to postestimation test using marginal effect analysis in order to estimate the trivial change from each factor that influences technical efficiency (TE). Quantification of the marginal effects of these variables is important in order to estimate the change that will occur with respect to a change in one unit of that variable. As shown in Table 4, the variables that were significant at 5\% level in the Tobit model have the highest change in production quantity per hectare $(\mathrm{Kg} / \mathrm{ha})$. This implies that a change in one unit of the variable in question would cause a bigger change in terms of $\mathrm{Kg} / \mathrm{ha}$ of sorghum harvested. For instance if hired labour is improved by one unit it will increase sorghum output by approximately $120 \mathrm{Kg} / \mathrm{ha}$ and $192 \mathrm{Kg} / \mathrm{ha}$ in Makindu and Machakos, respectively.

\section{Conclusion and Recommendation}

In this study factors influencing technical efficiency of sorghum production were investigated in a sample of 143 sorghum producing households in lower eastern Kenya using both descriptive statistics and Tobit models. The empirical findings show that some variables such as the formal education levels of the HHHs, years of sorghum farming experience, membership in farmer associations, land sizes planted with sorghum, hired labour, use of manure, and farmers receiving production advice all displayed positive technical efficiency regimes at 5\% statistical significance level. This implies that an increase or a decrease in any of these variables would cause an increase or a decrease in technical efficiency of sorghum production, respectively. Although negative, the household size was found statistically significant at 5\% level implying that an increase of the household size would decrease the technical efficiency and vice versa.

Sorghum farmers are not fully technically efficient and therefore there is room for efficiency improvement, which can be undertaken by addressing important variables that either positively or negatively influence levels of technical efficiency in the lower eastern Kenya through policy formulation or review. Formal education is an important positively influencing factor of technical efficiency in sorghum production. Thus appropriate policy formulation and/or review should be 
TABLE 4: Marginal effect results showing the change expected from a unit change in each variable in the lower eastern Kenya.

\begin{tabular}{|c|c|c|c|c|c|c|c|c|c|}
\hline \multirow{2}{*}{ Variables } & \multicolumn{3}{|c|}{ Overall } & \multicolumn{3}{|c|}{ Makindu district } & \multicolumn{3}{|c|}{ Machakos district } \\
\hline & $\Delta$ in $\mathrm{TE}$ & $\% \Delta$ in $\mathrm{TE}$ & $\Delta$ in $\mathrm{Kg} / \mathrm{ha}$ & $\Delta$ in $\mathrm{TE}$ & $\% \Delta$ in TE & $\Delta$ in $\mathrm{Kg} / \mathrm{ha}$ & $\Delta$ in $\mathrm{TE}$ & $\% \Delta$ in $\mathrm{TE}$ & $\Delta$ in $\mathrm{Kg} / \mathrm{ha}$ \\
\hline Male-headed HHs & 0.01512 & 1.51 & 9.47 & 0.0126535 & 1.27 & 7.69 & -0.1275 & 12.75 & 87.98 \\
\hline Age of the $\mathrm{HHH}$ & 0.00312 & 0.31 & 1.95 & -0.004085 & -0.41 & -2.48 & 0.0043 & 0.43 & 2.94 \\
\hline $\begin{array}{l}\text { Education of the } \\
\mathrm{HHH}\end{array}$ & $0.33971^{*}$ & 33.97 & 212.65 & $0.316089^{*}$ & 31.61 & 192.21 & $0.3861^{*}$ & 38.61 & 266.46 \\
\hline $\mathrm{HH}$ size & -0.01088 & -1.08 & -8.99 & $-0.0158526^{*}$ & -1.58 & -9.64 & -0.0143 & -1.43 & -9.87 \\
\hline $\begin{array}{l}\text { Number of } \\
\text { dependents }\end{array}$ & 0.01866 & 1.86 & 11.68 & 0.0334479 & 3.34 & 20.34 & 0.0010 & 0.10 & 0.69 \\
\hline Assets & $1.41 e-08$ & $1.41 e-06$ & $8.82 e-06$ & $2.81 e-08$ & $2.81 e-06$ & $1.71 e-05$ & $1.48 e-07$ & $1.48 e-05$ & $1.02 e-04$ \\
\hline $\begin{array}{l}\text { Experience in } \\
\text { sorghum farming }\end{array}$ & $0.13462^{*}$ & 13.46 & 84.27 & $0.0455824^{*}$ & 4.56 & 27.72 & $0.1420^{*}$ & 14.20 & 97.99 \\
\hline $\begin{array}{l}\text { Membership in } \\
\text { farmer association }\end{array}$ & $0.14459^{*}$ & 14.45 & 90.51 & $0.1932501^{*}$ & 19.33 & 117.52 & $0.3164^{*}$ & $31.64^{*}$ & 218.38 \\
\hline Seed rate used & 0.00003 & 0.003 & 0.02 & 0.0002828 & 0.03 & 0.17 & 0.0009 & 0.09 & 0.65 \\
\hline $\begin{array}{l}\text { Use of improved seed } \\
\text { variety }\end{array}$ & 0.06167 & 6.17 & 38.61 & 0.0087944 & 0.87 & 5.35 & 0.0237 & 2.37 & 16.38 \\
\hline $\begin{array}{l}\text { Size of land planted } \\
\text { with sorghum }\end{array}$ & 0.13176 & 13.18 & 82.48 & $0.5603131^{*}$ & 56.03 & 340.73 & $0.4210^{*}$ & 42.10 & 290.57 \\
\hline $\begin{array}{l}\text { Land preparation } \\
\text { method }\end{array}$ & -0.06263 & -6.26 & -39.20 & -0.042962 & -4.29 & -26.13 & -0.0455 & -4.55 & -31.43 \\
\hline Hired labour & $0.10958^{*}$ & 10.96 & 68.59 & $0.196799^{*}$ & 19.68 & 119.68 & $0.2789^{*}$ & 27.89 & 192.49 \\
\hline Manure use & $0.18316^{*}$ & 18.32 & 114.65 & $0.166^{*}$ & 16.60 & 100.95 & $0.2706^{*}$ & 27.06 & 186.75 \\
\hline Production advice & $0.26101^{*}$ & 26.10 & 163.38 & $0.2474189^{*}$ & 24.74 & 150.46 & $0.2208^{*}$ & 22.08 & 152.39 \\
\hline HH off-farm income & $-9.26 e-07$ & $-9.26 e-05$ & $-5.7 e-04$ & $1.28 e-06$ & $1.28 e-04$ & $7.78 e-04$ & $1.38 e-08$ & $1.38 e-06$ & $9.52 e-06$ \\
\hline Credit use & 0.10218 & 10.22 & 63.96 & 0.1060954 & 10.61 & 64.52 & 0.1157 & 11.57 & 79.82 \\
\hline $\begin{array}{l}\text { Income from other } \\
\text { farm activities }\end{array}$ & -0.00571 & -0.57 & -3.58 & 0.1156674 & 11.57 & 70.34 & -0.0622 & -6.22 & -42.92 \\
\hline Region & 0.10147 & 10.15 & 63.52 & - & 一 & & 一 & - & \\
\hline $\begin{array}{l}\text { Current mean } \\
\text { productivity }(\mathrm{Kg} / \mathrm{Ha})\end{array}$ & & 625.97 & & & 608.11 & & & 690.12 & \\
\hline
\end{tabular}

Notes: ${ }^{*}$ significant at 5\%, HHs: households, and HHH: household head.

undertaken to provide an enabling environment to encourage related basic education for both the old and young farmers. Educated youth should be encouraged to take up agricultural farming as a business by creating market diversified enterprises through value addition.

Given that membership to collective actions positively influences technical efficiency of sorghum production, it is recommended that formulation and implementation of appropriate policies that encourage farmers to form and join collective actions such as cooperatives and farmers' associations be instituted and strengthened. Production advice through provision of appropriate extension services delivery should be encouraged since this was found positively associated with technical efficiency. The government is thus advised to increase the deployment of more extension officers to rural areas to facilitate dissemination of new agricultural technologies.

Since manure had a positive influence on technical efficiency, its use should be encouraged through training farmers on how to make farm yard manure or compost manure using local materials at their disposal. Farmers should further be encouraged to plough their lands before planting as this increases the rates of water infiltration into the soil, thus reducing water run-offs that causes soil erosion. As a consequence all these will lead to increases in technical efficiency of sorghum by bigger margins as indicated by the marginal effect results.

\section{Disclaimer}

Any views expressed here are those of the authors and any errors are the sole responsibility of the authors.

\section{Conflict of Interests}

The authors declare that there is no conflict of interests regarding the publication of this paper.

\section{Acknowledgment}

The authors are grateful for Integrated Management of Water for Productivity and Livelihood Security under Variable and Changing Climatic Conditions in Eastern and Central Africa, 
a project supported by Association for Strengthening Agricultural Research in Eastern and Central Africa (ASARECA) for the funding support for this research.

\section{References}

[1] U.S Grain Council, Sorghum: U.S Grain Council, 2010, http:// www.grains.org/tags/sorghum.

[2] International Research Network, Grain Production in Kenya, EPZ, Nairobi, Kenya, 2005.

[3] Government of Kenya, "Arid and Semiarid lands," Northern Kenya and Other Arid Lands Ministry Report, Government Printers, Nairobi, Kenya, 2009.

[4] K. N. Olembo, F. M'mboyi, S. Kiplagat, and J. O. Sitieney, Sorghum Breeding in Sub-Saharan Africa: The Success Stories, African Biotechnology Stakeholders Forum, Nairobi, Kenya, 2010.

[5] L. Nagarajan and P. A. Audi, Seed Provision and Drylands Crops in the Semiarid Regions of Eastern Kenya, IFPRI, Washington, DC, USA, 2007.

[6] L. Ochieng, P. Mathenge, and R. Muasya, "A survey of onfarm seed production practices of sorghum (Sorghum bicolor L. Moench) in Bomet District of Kenya," African Journal of Food, Agriculture, Nutrition and Development, vol. 11, no. 5, pp. 270276, 2011.

[7] I. K. Okuthe, The influence of istitution factor on adoption of improved sorghum varieties and technologies by smallscale farmers in Ndhiwa Division, Homabay District, Kenya [M.S. thesis], Egerton University, Nakuru, Kenya, 2008.

[8] Government of Kenya, Economic Review of Agriculture, Ministry of Agriculture, Nairobi, Kenya, 2010.

[9] D. Karanja, C. Kamau, L. Muthoni et al., "Improving food security and income of farmers in ASALs through commercialization of gadam sorghum project," Unpublished Report, KARIKaumani, Machakos, Kenya, 2009.

[10] H. Fried, K. Lovell, and S. Schmidt, The Measurements of Productive Efficiency and Productivity Growth, Oxford University Press, New York, NY, USA, 2008.

[11] S. Chiona, Technical and allocative efficiency of smallholder maize farmers in Zambia [M.S. thesis], University of Zambia, Lusaka, Zambia, 2011.

[12] B. C. Chimai, Determinants of technical efficiency in smallholder sorghum farming in Zambia [M.S. thesis], Ohio State University, Columbus, Ohio, USA, 2011.

[13] S. A. Yusuf and O. Malomo, "Technical efficiency of poultry egg production in Ogun State: a Data Envelopment Analysis (DEA) approach," International Journal of Poultry Science, vol. 6, no. 9, pp. 622-629, 2007.

[14] O. Abu, "Fertilizer usage and technical efficiency of rice farms under tropical conditions: a data envelopment analysis," Journal of Agricultural Science, vol. 2, no. 2, pp. 83-87, 2011.

[15] B. Kibaara, Policy Brief: Technical Efficiency in Kenya's Maize Production. The Stochastic Frontier Approach, Tegemeo Institute, Nairobi, Kenya, 2005.

[16] J.-P. Chavas, R. Petrie, and M. Roth, "Farm household production efficiency: evidence from the Gambia," American Journal of Agricultural Economics, vol. 87, no. 1, pp. 160-179, 2005.

[17] D. O. Nyagaka, G. A. Obare, J. M. Omiti, and W. Nguyo, "Technical efficiency in resource use: evidence from smallholder irish potato farmers in Nyandarua North District, Kenya," African
Journal of Agricultural Research, vol. 5, no. 11, pp. 1179-1186, 2010.

[18] A. E. Ahmed, F. Kuhlmann, M. Mau, H. A. Elobeid, and E. M. Elamin, "Analysis of factors affecting sorghum production in the Gezira scheme-Sudan and implication on the household food security," in Proceedings of the Conference on International Agricultural Research for Development, Tropentag, StuttgartHohenheim, Germany, October 2005.

[19] W. G. Tyler, "Technical efficiency in production in a developing country: an empirical examination of the Brazilian plastics and steel industries," Oxford Economic Papers, vol. 31, no. 3, pp. 477495, 1979.

[20] D. Kariuki, C. Ritho, and K. Munei, "Analysis of the effect of land tenure on technical efficiency in smallholder crop production in Kenya," in Proceedings of tje Conference of International Research on Food Security, Natural Resource Management and Rural Development, University of Hohenheim, Stuttgart, Germany, 2008.

[21] I. W. Chirwa, "Sources of technical efficiency among smallholder maize farmers in Southern Malawi," AERC Research Paper 172, African Economic Research Consortium, Nairobi, Kenya, 2007.

[22] T. Coelli, S. Rahman, and C. Thirtle, "Technical, allocative, cost and scale efficiencies in Bangladesh rice cultivation: a nonparametric approach," Journal of Agricultural Economics, vol. 53, no. 3, pp. 607-626, 2002.

[23] E. Chepng'etich, E. K. Bett, S. O. Nyamwaro, and K. Kizito, "Analysis of technical efficiency of sorghum production in lower Eastern Kenya: a data envelopment analysis (DEA) approach," Journal of Economics and Sustainable Development, vol. 5, no. 4, pp. 58-65, 2014.

[24] D. N. Gujarati, Essentials of Econometrics, McGraw-Hill, New York, NY, USA, 3rd edition, 2006.

[25] E. C. Mussa, G. A. Obare, A. Bogale, and F. Simtowe, Resource Use Efficiency of Smallholder Crop Production in the Central Highlands of Ethiopia, IFPRI, Washington, DC, USA, 2011.

[26] M. I. Javed, S. A. Adil, A. Ali, and M. A. Raza, "Measurement of technical efficiency of rice-wheat system in punjab," Journal of Agricultural Resource, vol. 48, no. 2, pp. 227-238, 2010.

[27] M. D. Padilla-Fernandez and P. L. Nuthall, “Technical efficiency in the production of sugarcane in central Negros area, Philippines. An application of DEA," Journal of International Society for Southeast Asian Agricultural Sciences, vol. 15, no. 1, pp. 77-90, 2009.

[28] M. Gul, B. Koc, E. Dagistan, M. G. Akpinar, and O. Parlakay, "Determination of technical efficiency in cotton growing farms in Turkey: a case study of Cukurova region," African Journal of Agricultural Research, vol. 4, no. 10, pp. 944-949, 2009.

[29] O. C. Ajewole and J. A. Folayan, "Stochastic frontier analysis of technical efficiency in dry season leaf vegetable production among smallholders in Ekiti State Nigeria," Agricultural Journal, vol. 3, no. 4, pp. 252-257, 2008.

[30] P. S. Amaza, Y. Bila, and A. C. Iheanacho, "Identification of factors that influence technical efficiency of food crop production in West Africa: empirical evidence from Borno State, Nigeria," Journal of Agriculture and Rural Development in the Tropics and Subtropics, vol. 107, no. 2, pp. 139-147, 2006.

[31] J. F. Shehu, J. T. Iyortyer, S. I. Mshelia, and A. U. Jongur, "Determinants of Yam production and technical efficiency among Yam farmers in Benue State, Nigeria," Journal of Social Science, vol. 24, no. 2, pp. 1437-148, 2010. 
[32] M. Elibariki and H. Shuji, "Explaining productivity variation among smallholder maize farmers in Tanzania," in Proceedings of the World Congress of Rural Sociology of the International Rural Sociology Association, Goyang, Republic of Korea, 2008.

[33] I. C. Idiong, "Estimation of farm level technical efficiency in smallscale swamp rice production in cross river of Nigeria: a stochastic frontier approach," World Journal of Agricultural Sciences, vol. 3, no. 5, pp. 653-658, 2007.

[34] J. Njeru, "Factors influencing technical efficiency on selected wheat farmers in Uasin Gishu District Kenya," AERC Reseach Paper 206, African Economic Research Consortium, Nairobi, Kenya, 2010.

[35] A. M. Wakili, “Technical efficiency of sorghum production in Hong local government area of Adamana State Nigeria," Russian Journal of Agricultural and Socio-Economic Sciences, vol. 6, no. 6, pp. 10-15, 2012.

[36] A. Nchare, "Analysis of factors affecting the technical efficiency of arabica coffee producers in Cameroon," AERC Research Paper 163, African Economic Research Consortium (AERC), Nairobi, Kenya, 2007. 


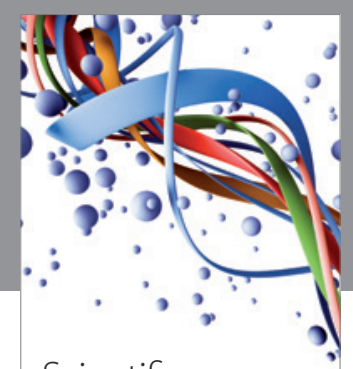

Scientifica
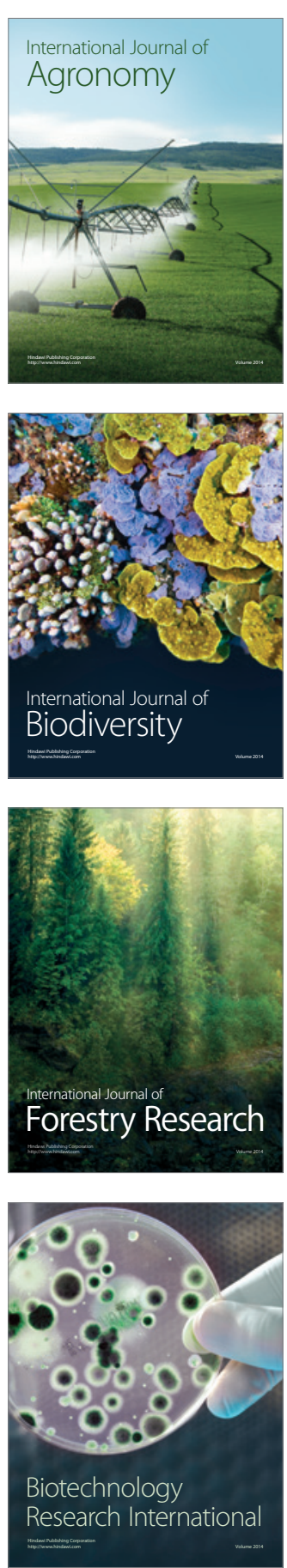
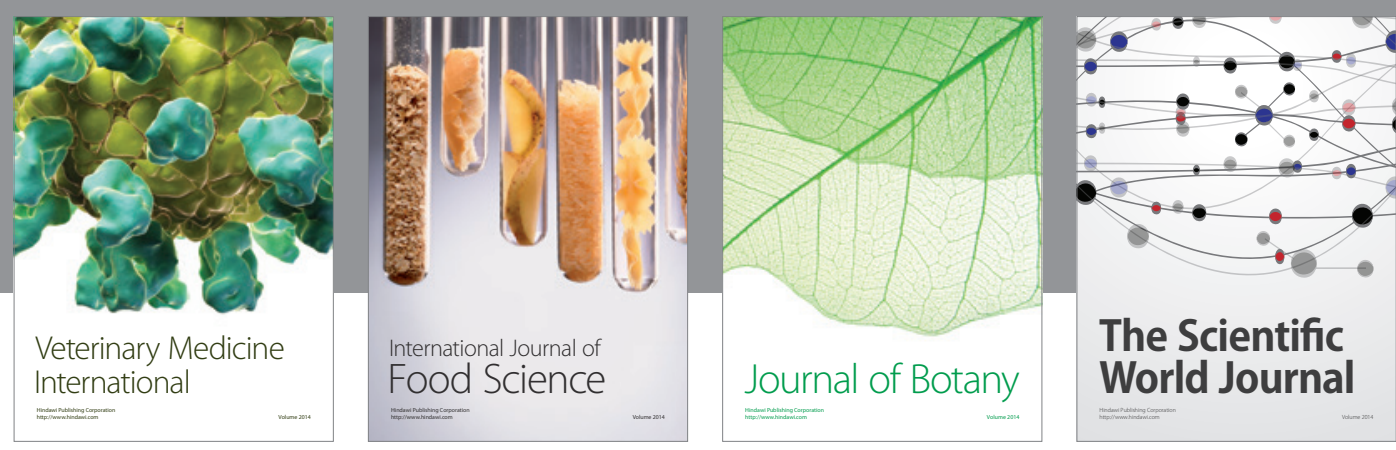

The Scientific World Journal
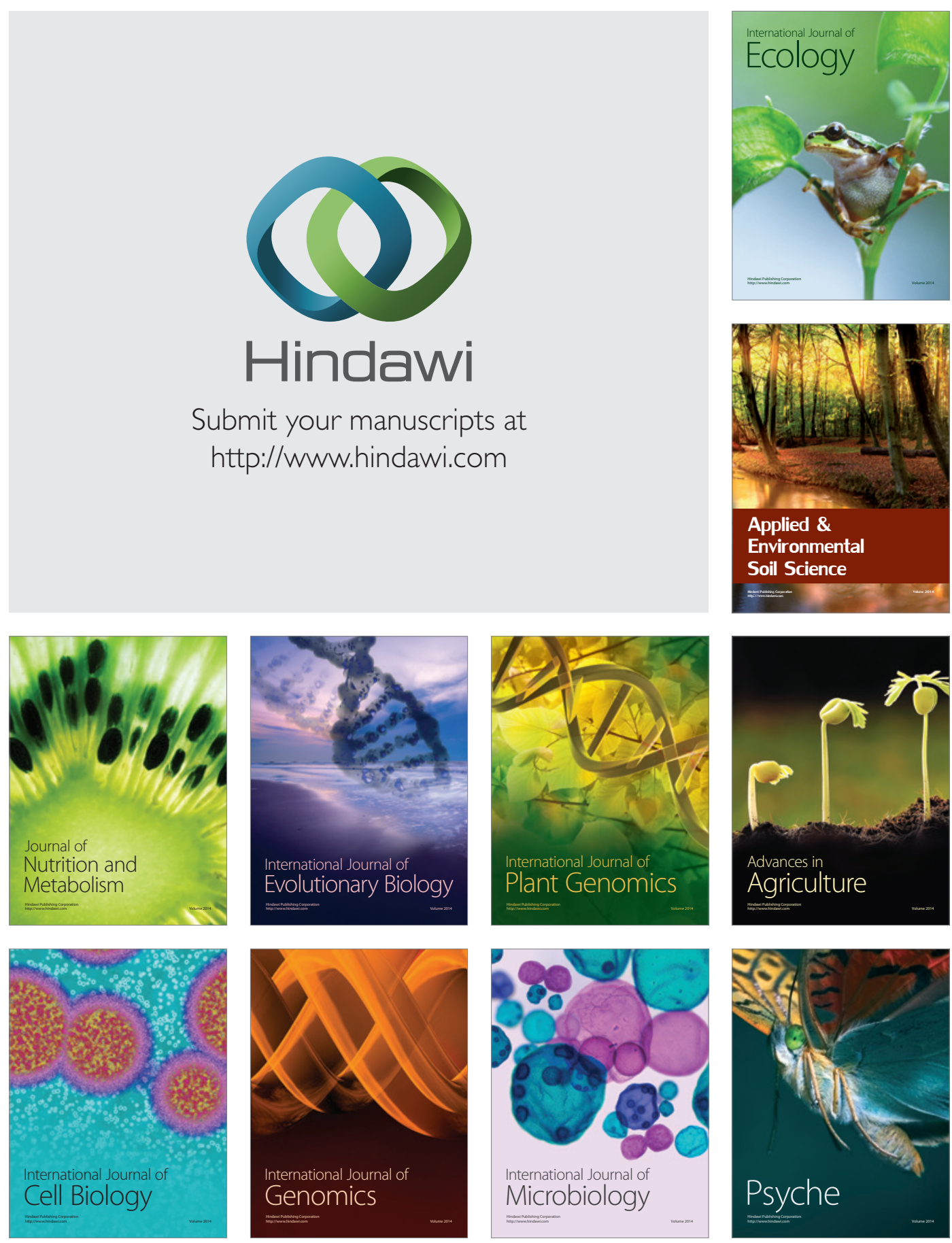